\title{
The placement of the Trans-European Suture Zone on the Romanian territory by electromagnetic arguments
}

\author{
Maria Stănică, Dumitru Stănică, and Cornelia Marin-Furnică \\ Geological Institute of Romania, Ro-78 344, Caransebeş Str. 1, Bucharest, Romania \\ (Received October 26, 1998; Revised February 25, 1999; Accepted May 4, 1999)
}

\begin{abstract}
Initially, two 2D models are presented in order to emphasize the possible placement of the Trans-European Suture in the rooted zone of the Eastern Carpathians' Flysch Nappes System. Then, a conclusive review of the distribution of the main geoelectrical properties on this area is accomplished, pointing out the accuracy of the image reflecting the two types of contrasting basement, without neglecting the complex aspect related to the Carpathian Arc Bend. By correlating the two maps, at the lower crust and basement levels, elaborated by electromagnetic data, new information concerning the particularities of this distinctive tectonic element are brought to light. In addition to it, the two extreme top limits on the map of the lower crust (brittle/ductile transition zone) are revealed-the highest one $(30 \mathrm{~km})$ eastwards of the Pannonian Basin, and the deepest one (about $50 \mathrm{~km}$ ) in the Vrancea area.
\end{abstract}

\section{Introduction}

Running over a distance of $2000 \mathrm{~km}$, the Trans-European Suture Zone (TESZ) is stratching from Denmark and the north German Lowlands, through Poland, Ukraine and Romania. It is documented by paleomagnetic data that this important geological boundary in Europe separates the mobile Phanerozoic terranes, in SW, from the ancient Precambrian structure of the East European Craton and Baltic Shield (Pharaoh and TESZ colleagues, 1996; Giese et al., 1998). This very complex zone is not clear enough, in the Central Europe, because it is obscured by overriding orogenic complexes - the Caledonide-Variscide, in west, and the Carpathians, in east. In these circumstances a direct geological investigation is not possible at all.

On the Romanian territory the TESZ is covered by the Carpathian thrust-belt of Alpine age and because of this reason just a few methods are available to decipher it. In general, the attempts of investigating the composition and the evolution of the crust and subcrustal lithosphere, by using only compressional-wave velocity, have met with a limited success (Musacchio and Mooney, 1998).

In order to reveal the placement of the main characteristics of the TESZ, inferred from the magnetotelluric (MT) data, this paper uses a vast storehouse summarizing the most significant geoelectrical cross-sections (Stănică et al., 1986; Stănică and Stănică, 1989, 1993, 1998; Pinna et al., 1992) accomplished on the profiles A, B, C, D, E and P (Fig. 1) crossing the Eastern Carpathians and surrounding areas, as well as the Dobrogean zone. In addition to MT data, the deep cross-sections include main geotectonic information after $\mathrm{M}$. Săndulescu, 1994. All these data are analysed and integrated in the larger context of the two structural maps concerning

Copy right (C) The Society of Geomagnetism and Earth, Planetary and Space Sciences (SGEPSS); The Seismological Society of Japan; The Volcanological Society of Japan; The Geodetic Society of Japan; The Japanese Society for Planetary Sciences. the lower crust and the cristallyne basement, elaborated on the basis of the MT results (Stănică, 1998) for the Romanian territory.

\section{Magnetotelluric Arguments}

So as it is well-known, the Trans-European paleosuture separating the old Europe (East European Craton), characterized by stable tectonics since the end of the Precambrian, from the younger Europe, characterized by mobile belts, is difficult to be investigated on surface as a sequence of the orogenic complexes is masking it. Therefore, some electromagnetic studies consisting in deep magnetotelluric soundings, presented on this occasion, try to contribute in deciphering the deep structure and the deep crustal root beneath TESZ.

The aim of this paper is to emphasize both the placement and the significance of the TESZ by means of MT data. These are presented as geoelectrical cross-sections elaborated especially after 2D forward modelling-finite element code (Wannamaker et al., 1987).

The geoelectric model elaborated on profile C (Fig. 2) is one of the most representative for this goal, because it contains the lithospheric electrical particularities of the northern profiles (Stănică et al., 1986) and the southern ones (Stănică and Stănică, 1998), too.

Mainly, it is about the presence of the most important conductivity anomaly (Carpathian Electrical Conductivity Anomaly, Fig. 1), corresponding to the rooted zone of the Flysch Nappes System, extended down as a major paleosuture separating on the basis of the electrical properties the two types of crust-what may be seen on all the northern profiles.

The information related to the southern profiles (D and E) are referring to the presence of the other important conductivity anomaly zone also corresponding to a main crustal fault, which was correlated with the Wiese's vectors divergence alignment mentioned in Pinna et al. (1992). 


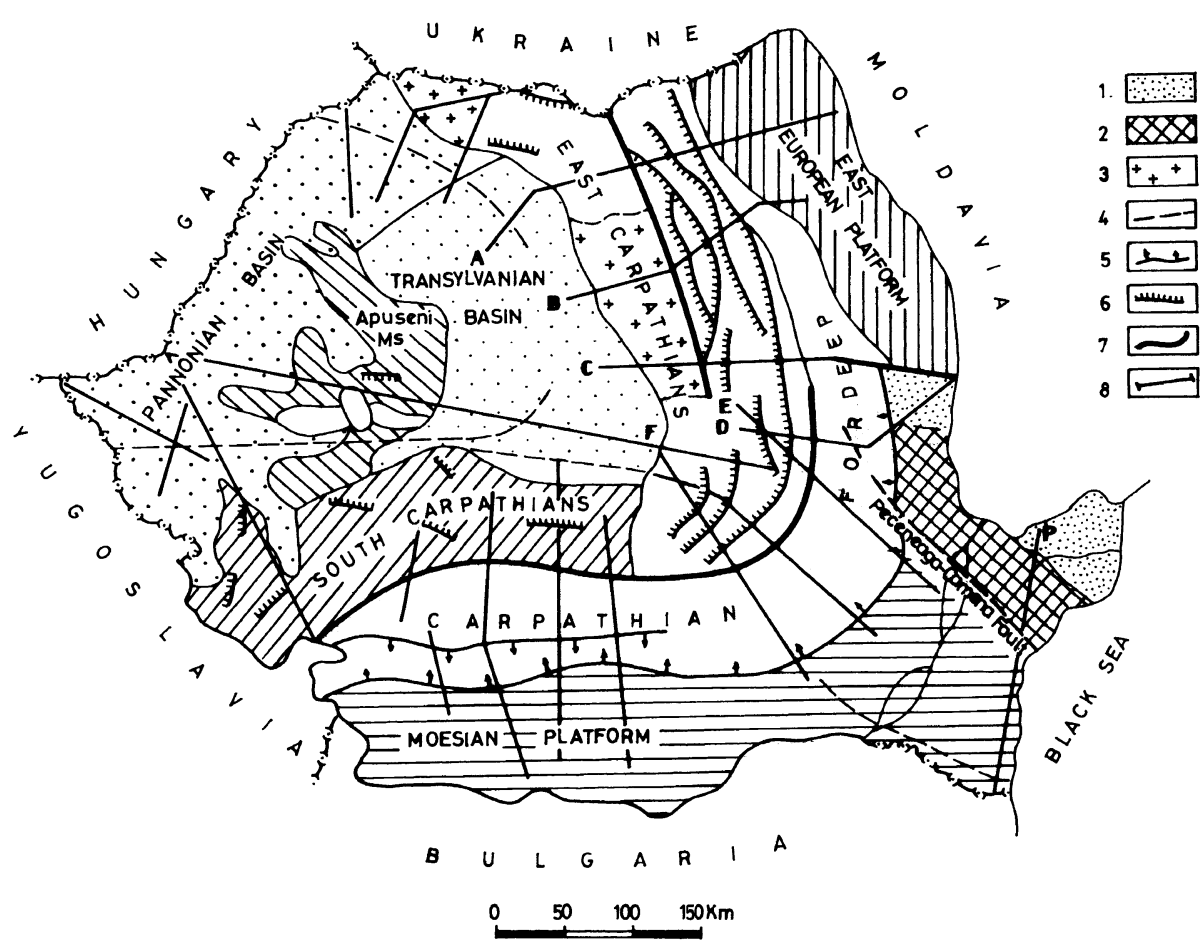

Fig. 1. The placement of the magnetotelluric profiles on tectonic sketch map. 1-Schythian Platform; 2-North Dobrogean Orogen; 3-Neogene volcanic chain; 4-Deep fault; 5-Flexure; 6-Thrust; 7-Carpathian electrical conductivity anomaly (CECA); 8-MT profiles.

It is important to point out the characteristics of these two fault zones as only one of them (Peceneaga-Camena Fault) emphasizes the contact between the two types of crust having different thickness and electrical properties-what may be the normal consequence of the different age.

This model (Fig. 2), by means of the resistivity contrast limits provided by 65 magnetotelluric soundings (MTS), brings into the light the new data concerning the deep structure of the crust that slopes in steps from ESE to WNW and comes below the thinner crust of the Transylvanian Basin. From east to west, the profile is crossing the Scytian Platform between MTS 1-MTS 20, then the Moesian Platform and Carpathian Orogen, finishing on the Transylvanian Depression. The thickness of the crust ranges from $36 \mathrm{~km}$ (Scythian Platform) to $45 \mathrm{~km}$ (Moesian Platform and Carpathian Orogen), and around $30 \mathrm{~km}$ (Transylvanian Depression).

On the Scythian and Foreland areas (Sites 1-17) the sedimentary formations have resistivities less than $10 \mathrm{ohm} . \mathrm{m}$ and thickness ranging from 5 to $10 \mathrm{~km}$. In the Moesian Platform and Flysch Zone the resistivity interfaces are generally represented with discernible contrasts, so that boundaries could be drawn up between the Flysch Nappes and the MesozoicPalaeozoic formations and/ or the basement of the Moesian Platform lying directly below (Stănică and Stănică, 1993).

A large occurrence of the Carpathian orogenic area is covered by the Flysch Zone, where the nappes are not easily differentiated and the geological information (Săndulescu, 1994) are absolutely necessary. But, all the MT data show that the Flysch Nappes, System is rooting from east to west, on the contact zone between two types of crust, interleaving them, where an important jump at the lower crust level is releaved, what may be conclusive arguments for assimilating this with TESZ. This contact zone has its own particularities related to the large width, crustal character and a thick cover of geological formations getting even $12-14 \mathrm{~km}$.

The next important geoelectrical limit is assesed as the top of the asthenosphere and its depth is estimated at $80 \mathrm{~km}$ (Transylvanian Basin) and 165-170 km for the other zones. Detailed information regarding the top limit of the asthenosphere are supplied in Stănică and Stănică (1993).

This profile was chosen to be discussed, related to the placement of TESZ, in order to define its southern extension, too, what is difficult enough to be argued. From northern Romanian boundary till the profile noted by $(\mathrm{C})$, only one main conductivity anomaly appears, as a prolongation of that from Ukraine, to which the TESZ is corresponding. On the profile $(\mathrm{C})$, two conductivity anomalies are presented, what means that we have to try to elucidate what does happen southwards. A first step was the analysis of the lower crust map (Fig. 3) where there are the main structural characteristics. No doubt, the disposition of the isobaths suggests clearly an eastern extention of the lower crust to the Dobrogean area, respectively Bleack Sea, what means that the alignment of the TESZ is corresponding to the Carpathian Orogen till North of the Carpathian Arc Bend (so called Vrancea zone, marked by a rectangle in Fig. 3) and its prolongation southwards is following the other major tectonic accident (Peceneaga-Camena Fault), so as it is inferred from the second geoelectrical model presented here (Fig. 4), elaborated on a closed profile noted by (D).

On this image, 31 MTS supply information related to both sedimentary cover and crust, as well as the main faults. MT data permitted us to differentiate various types of basement and sedimentary layers. The model also reveals the presence 


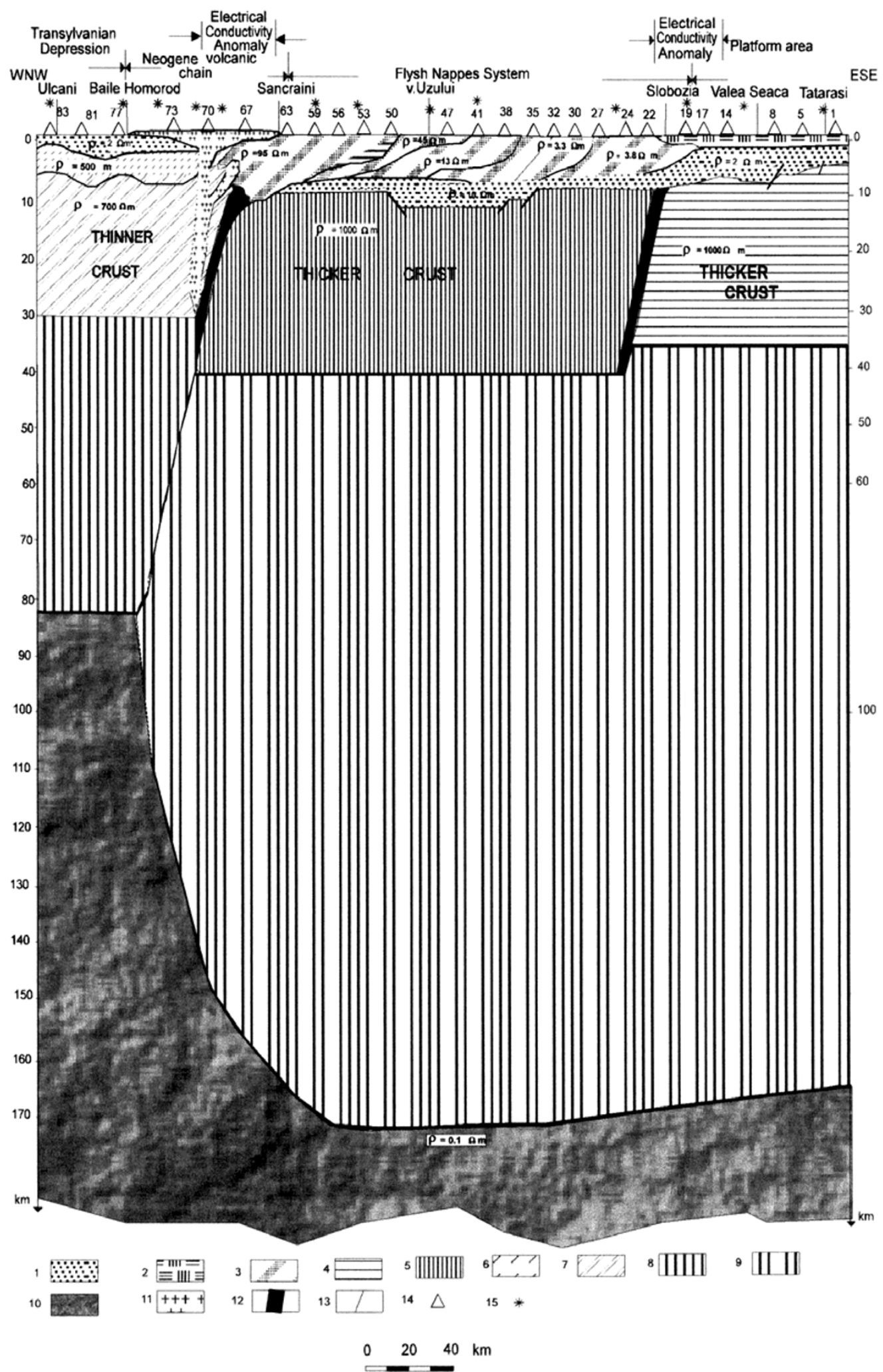

Fig. 2. Geoelectrical cross-section on the profile C: 1, 2-Sedimentary cover of the Moesian Platform and Transylvanian Depression; 3-Flysch Nappes System; 4-The folded basement of the Scythian Platform; 5-The folded basement of the Moesian Platform; 6-The Central-East Carpathian Nappes; 7-The folded basement of the Transylvanian Depression; 8-The upper mantle of the Transylvanian Depr.; 9-The upper mantle of the Scythian and Moesian Platforms; 10-Asthenosphere; 11-Volcanic and subvolcanic formations; 12-High conductivity zone; 13-Fault; 14-MT location (frequency range: $20-0.001 \mathrm{~Hz}$ ); $15-\mathrm{MT}$ location (frequency range: $1-0.0001 \mathrm{~Hz}$ ). 

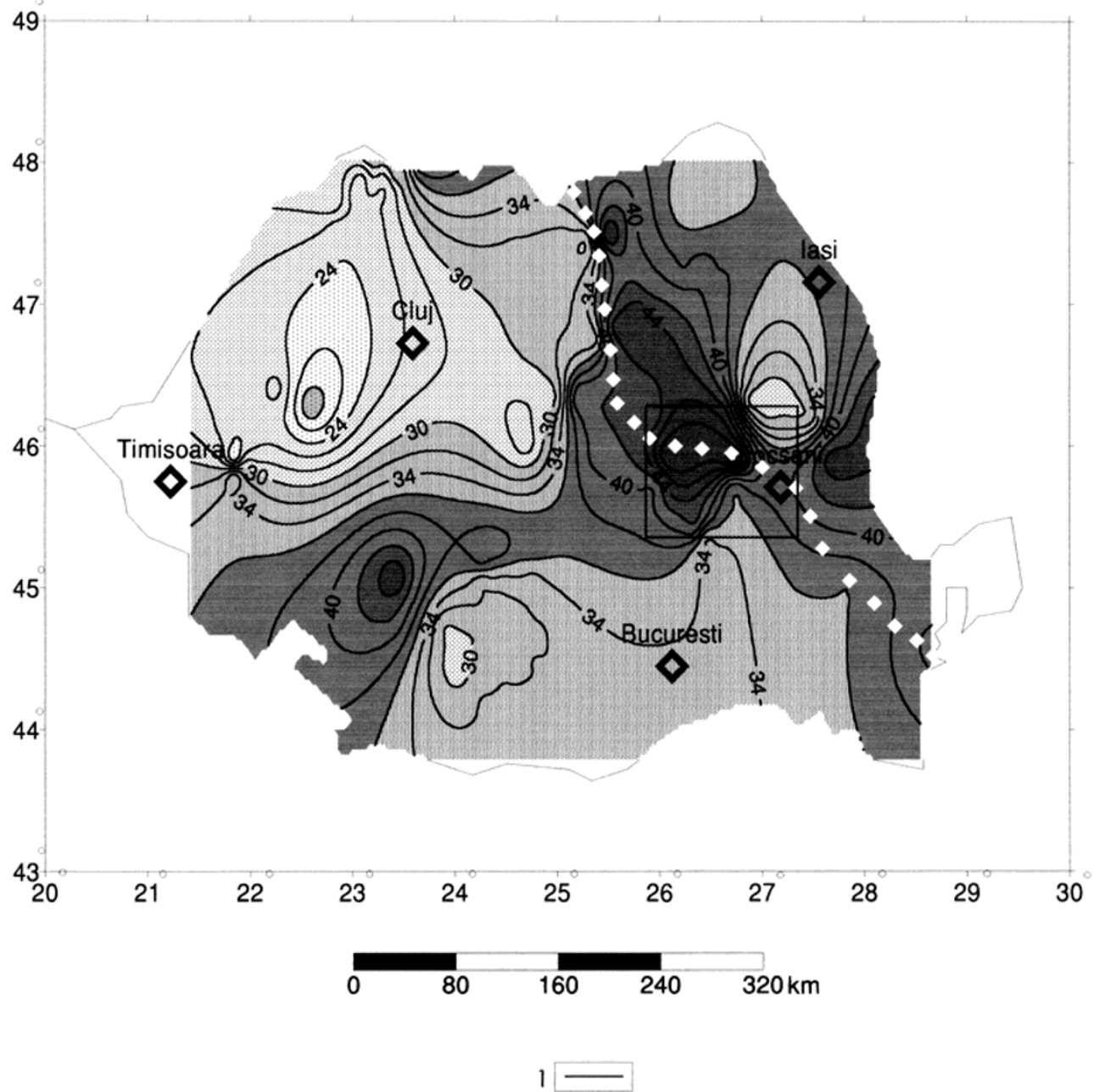

Fig. 3. The map of the lower crust (the top of the brittle/ductile zone). 1-isobath in km; white rhombs represent the placement of the TESZ; rectangle marks Vrancea zone.

of a transition zone from brittle to ductile at $50 \mathrm{~km}$, between MTS 2-MTS 22, having a resistivity of 7-9 ohm.m, $27 \mathrm{~km}$ between MTS 22-MTS 27, where the resistivity is around $2 \mathrm{ohm} . \mathrm{m}$, and $35-36 \mathrm{~km}$ to NE, between MTS 27MTS 38, where the resistivity is ranging from 2 to 3, even 14 ohm.m. From WNW the profile is crossing the Carpathian Orogen (MTS 2-16), Moesian Platform (MTS 16-22), North Dobrogean Orogen (MTS 22-27) and Scythian Platform.

\section{Conclusions}

The placement of the TESZ on the Romanian territory is rather complicated and difficult to draw up taking into account the Carpathian thrust-belt which cover it. Nevertheless, the MT data have brought valuable information for deciphering the lithospheric electrical particularities of the TESZ and its surrounding areas.

Evidences provided by MT data define the electrical constitution and thickness of the crust and upper mantle, the geometry and interrelation between young terranes (Transylvanian Depression and Moesian Platform), westwards, and the old ones (Scythian and East-European Platforms), eastwards. In this context, is very easy to demonstrate that this interrelation may be associated both the
Carpatian electrical conductivity anomaly (CECA), in the Eastern Carpathians, and the major crustal-subcrustal faults system (Peceneaga-Camena Fault) separating the Moesian Platform from North Dobrogean Orogen, in the Arc Bend area, and the Scythian and Moesian Platforms, in Dobrogea zone (Stănică and Stănică, 1989). The increase of electrical conductivity in the collision area (continent-continent subduction zone) may be attributed to the presence of the graphitic films along the Alpine palaeo-plane of "consumption" as a result of the important compressional regime and tectonic activity. Graphitic zones have been interpreted as tectonic markers possibly related to old collision areas by Korja and Hjelt (1993). Also, they document extensive outcrops of graphitic shales apparently associated with active and fossilised subduction zones.

Along and around the TESZ magnetotelluric data point out sedimentary basins (Fig. 5), Permo-Mesozoic in age, with the same rheologic peculiarities as those known in the Carpathian Foreland of Poland (Pharaoh and TESZ colleagues, 1996).

The most important result is that the TESZ produces a deplacement of about $10-15 \mathrm{~km}$ of the lower crust indicating the top of brittle/ductile transition zone, belonging to both the Phanerozoic terranes (at about $30 \mathrm{~km}$ depth) and East- 


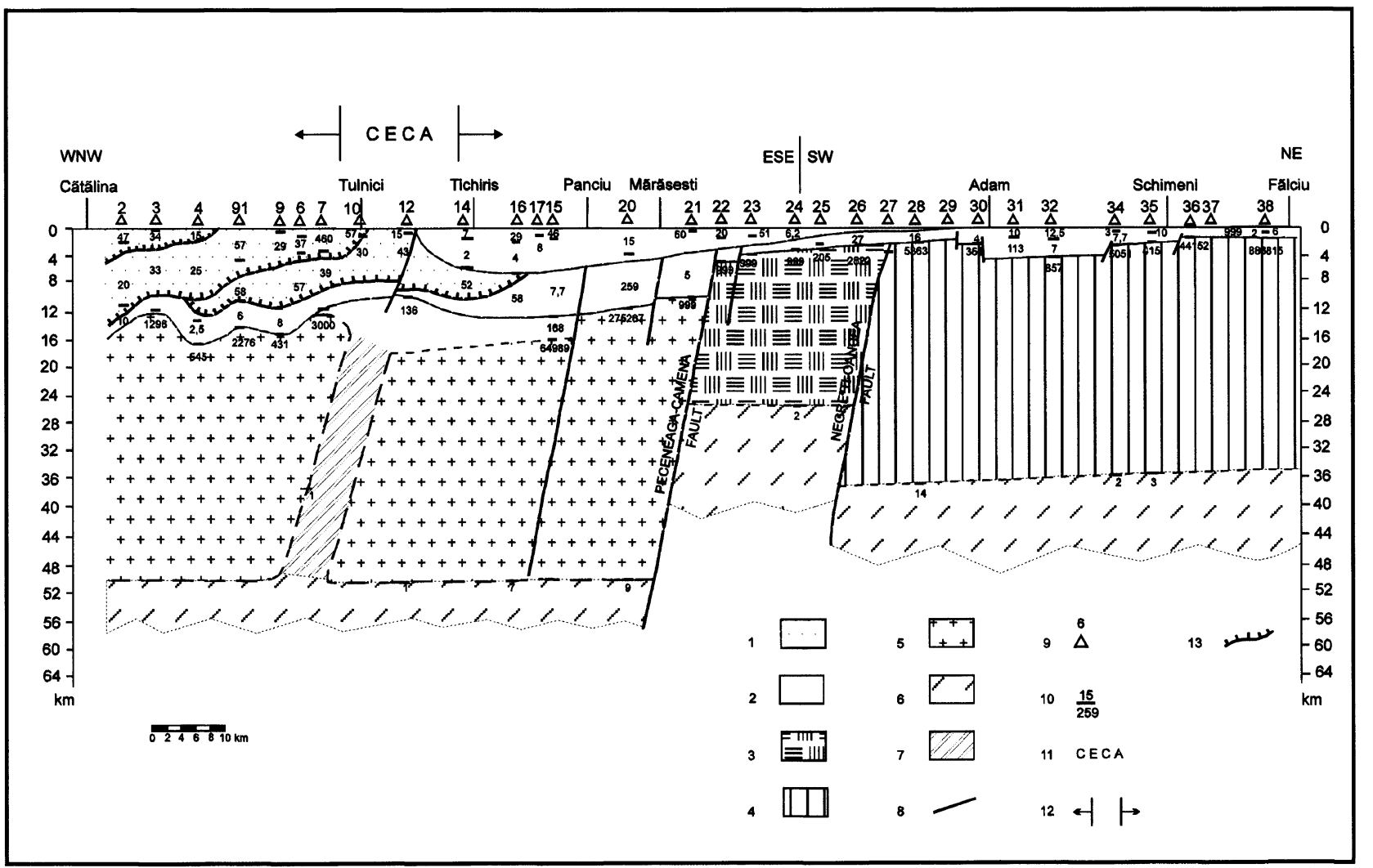

Fig. 4. Geoelectrical cross-section on the profile D: 1-Flysch Nappes System; 2-Sedimentary cover, 3-North Dobrogean Orogen; 4-Folded basement of the Scythian Platform; 5-The folded basement of the Moesian Platform; 6-The upper mantle; 7-High conductivity zone; 8-Fault; 9-MT location; 10-Limit of the resistivity contrast; 11-Carpathian electrical conductivity anomaly; 12-Zone of divergence of Wiesse's vectors; 13-Thrust.

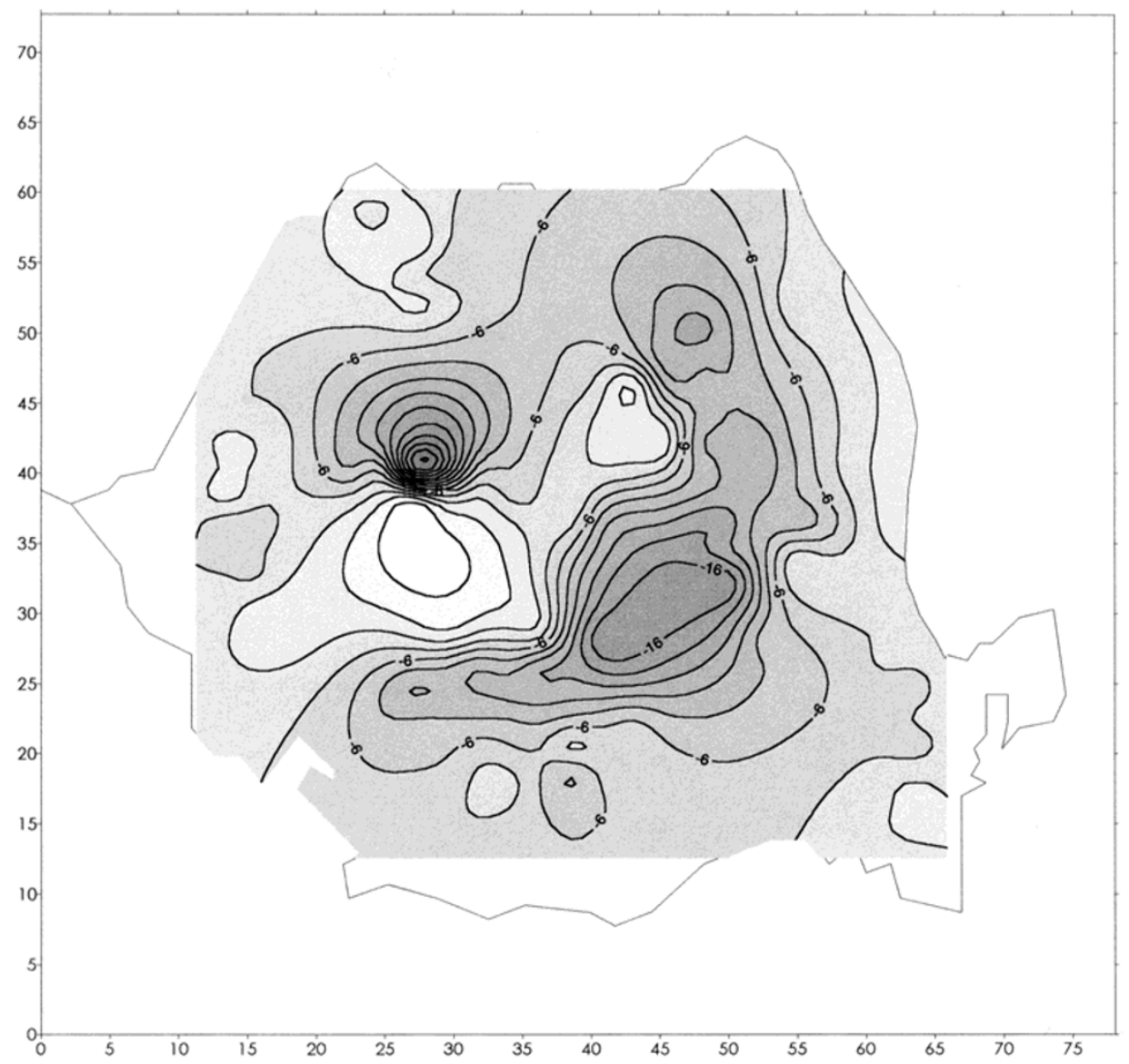

Fig. 5. The map of the basement level (isobath in km). 
LITHOSPHERIC MODEL

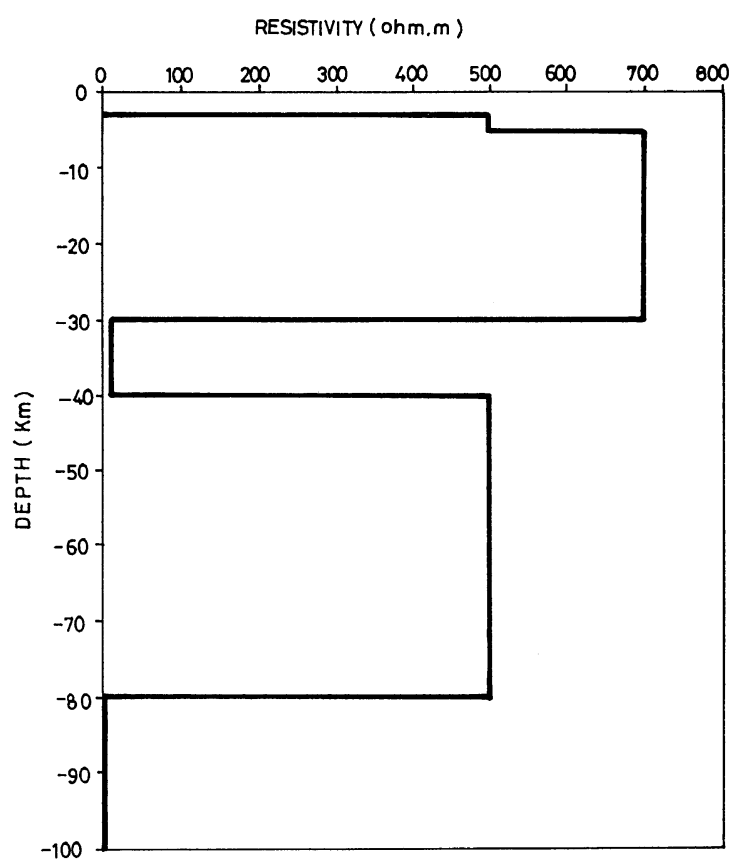

Fig. 6. Lithospheric model, adopted from a full 2D forward modelling and inversion. The solid line shows the resistivity distribution beneath Transylvanian Basin, with high conductivity in the lower crust (30-40 $\mathrm{km}$ depth) and a conductive upper mantle zone (asthenosphere) below $80 \mathrm{~km}$.

\section{LITHOSPHERIC MODEL}

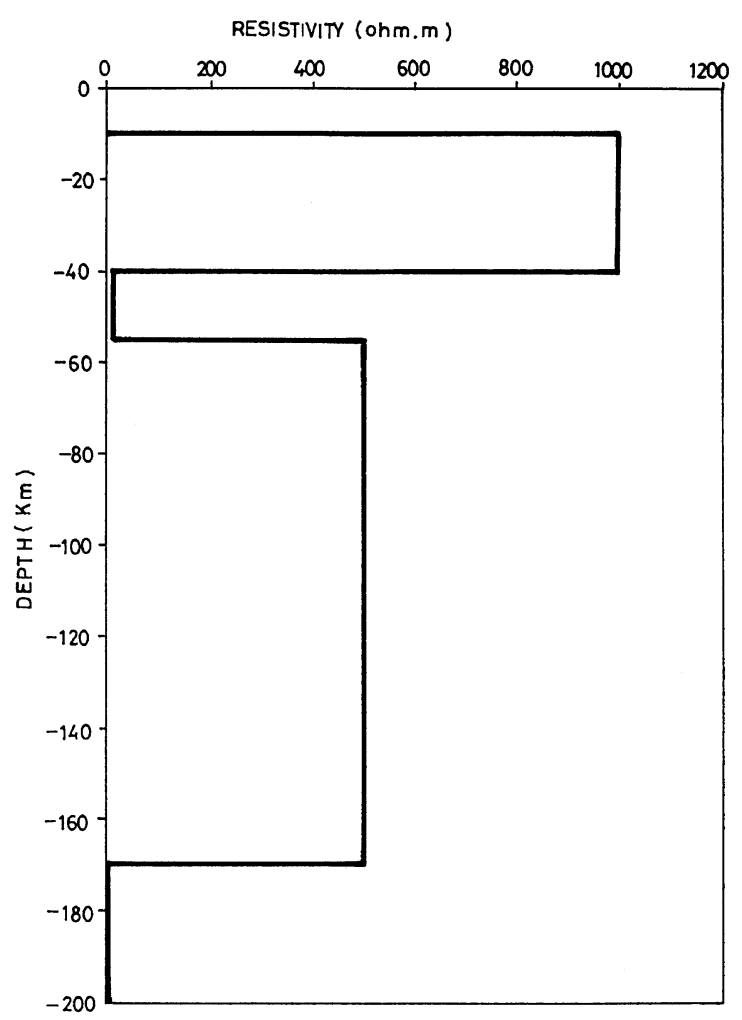

Fig. 7. Lithospheric model, adopted from a full 2D forward modelling and inversion. The solid line shows the resistivity distribution beneath the Scythian and East European Platforms, with high conductivity in the lower crust (40-55 km) and a conductive upper mantle zone (asthenosphere) below $170 \mathrm{~km}$.
European Craton (40-45 km), respectively.

The results of MT soundings carried out on the both sides of the TESZ are summarized in two lithospheric models (Figs. 6 and 7) obtained by using 2D forward modelling (finite element code, described by Wannamaker et al., 1987). For a two dimensional model we parameterized the earth by means of a grid of rectangular cells, each having an uniform conductivity. In order to determine the sizes of the resistivity blocks, we make an estimation of the resistivity based on 1$\mathrm{D}$ inversion of the TE mode and inspection of the $\rho_{a}$ curves (details in Stănică and Stănică, 1998).

Acknowledgments. This study was partly supported by scientific grants/1997 awarded by the Romanian Academy of Sciences and Ministry of Research and Technology. The authors thank to the Geological Institute of Romania for providing MT data and other facilities for the present research project. The two anonymous referees are thanked for the usefull comments on the manuscript.

\section{References}

Giese, U., G. Katzung, and U. Kramm, The TransEuropean Suture Zone in NE-Germany-Implications and constraints from structural studies, provenance analysis and isotope dating, Ann. Geophys., Suppl. I, 16, C105, EGS, Nice, 1998, (Abstract).

Musacchio, G. and W. D. Mooney, Composition, structure and evolution of Precambrian crust: evidence from Vp/Vs ratios, Ann. Geophys., Suppl. I, 16, C108, 1998, (Abstract).

Korja, T. and S.-E. Hjelt, Electromagnetic studies in the Fennoscandian Shield-electrical conductivity of Precambrian crust, Phys. Earth Planet. Inter, 81, 107-138, 1993

Pharaoh, T. and TESZ colleagues, Trans-European Suture Zone: Phanerozoic Accretion and the Evolution of Contrasting Continental Lithosphere, EUROPROBE 1996-Lithosphere Dynamics: Origin and Evolution of Continents, 41-54, Europrobe Secretariate, Uppsala University, 1996.

Pinna, E., A. Soare, D. Stănică, and M. Stănică, Carpathian conductivity anomaly and its relation to deep substratum structure, Acta Geodaet. Geophys. Mont. Hung., 27, 35-45, 1992.

Săndulescu, M., Overview on Romanian Geology, Rom. Jour. of Tectonics and Regional Geology, Suppl. 2, 75, 3-15, Bucharest, 1994.

Stănnică, D., M. Stănică, and M. Visarion, The structure of the crust and upper mantle in Romania as deduced from magnetotelluric data, Rev. Roum. Geol. Geophys. Geogr., Ser. Geophys., 30, 25-35, Bucharest, 1986.

Stănică, D. and M. Stănică, The investigation of the deep structure of the Moesian Platform (Romania) by means of the electromagnetic induction methods, Gerlands Beitr. Geophysik, 98(2), 155-163, Leipzig, 1989.

Stănică, D. and M. Stănică, An electrical resistivity lithospheric model in the Carpathian Orogen from Romania, Phys. Earth Planet. Inter., 81, 99-105, 1993

Stănică, M. and D. Stănică, 2D modelling of the geoelectrical structure in the area of the deepfocus Vrancea earthquakes, in Monograph. of Southern Carpathians. Reports on Geodesy, pp. 153-203, Warsaw, 1998.

Stănică, M., Approach of the tectonical active zones (Vrancea area) by magnetotelluric soundings, Ann. Geophys. Suppl. I, 16, C281, Nice, 1998, (Abstract).

Wannamaker, P. E., J. A. Stodt, and L. Rijo, A stable finite element solution for two-dimensional magnetotelluric modeling, Geophys. J. R. astr. Soc., 88, 277-296, 1987.

M. Stănică (e-mail: stanica@ns.igr.ro), D. Stănică, and C. Marin-Furnică 